\title{
Obstetric practices performed by nurse-midwives of a hospital natural birth center
}

\author{
Práticas obstétricas em centro de parto normal intra-hospitalar realizadas por enfermeiras obstetras \\ Prácticas obstétricas en centro de parto normal intrahospitalario realizadas por enfermeras obstetras
}

\author{
Juliana Manoela dos Santos Freitas ${ }^{1}$ (D) \\ Nádia Zanon Narchi ${ }^{2}$ (D) \\ Rosa Aurea Quintella Fernandes ${ }^{1}$ (D)
}

1. Universidade Univeritas.

Guarulhos, SP, Brasil.

2. Universidade de São Paulo.

São Paulo, SP, Brasil.
Corresponding author:

Rosa Aurea Quintella Fernandes.

E-mail: fernands@uol.com.br

Submitted on 04/12/2019.

Accepted on 06/11/2019.

DOI: 10.1590/2177-9465-2019-0112

\section{Abstract}

Objectives: To characterize the practices used by nurse-midwives in a Natural Birth Center (NBC) and to verify the maternal and neonatal outcomes. Method:This was a cross-sectional, documentary, retrospective study with a quantitative approach in which the medical records of 300 parturients who gave birth in a state hospital in the city of São Paulo were analyzed. The categories of the World Health Organization (WHO) composed the criteria adopted for the analysis of the obstetric practices. Fisher's exact test or the likelihood ratio and Student t-test were used. Results: The nurse-midwives mostly used category A practices of the WHO. There were no statistically significant associations between practices and perineal outcomes. There was a statistically significant association between the weight of the newborn and the number of neonatal complications, as well as between the delivery position of the primiparous women and clavicle fractures of the newborns. Conclusion and implications for the practice: Evidence-based practices were followed by the nurse-midwives in the NBC analyzed. The maternal and neonatal outcomes were adequate. There is a need to improve care in the second stage of the delivery in order to avoid behaviors that reflect in neonata complications. The study makes it possible to reflect on the importance of the continuous evaluation of the care provided.

Keywords: Childbirth care; Women's health; Natural birth; Labor; Nurse-midwives.

\section{REsUMO}

Objetivos: Caracterizar as práticas utilizadas pelas enfermeiras obstetras em um Centro de Parto Normal (CPN) e verificar os desfechos maternos e neonatais. Método: Estudo transversal, documental, retrospectivo, com abordagem quantitativa. Analisaram-se prontuários de 300 parturientes que deram à luz em hospital estadual da cidade de São Paulo. Os critérios adotados para a análise das práticas obstétricas foram as categorias da Organização Mundial da Saúde (OMS). Utilizaram-se os testes exatos de Fisher ou razão de verossimilhança (Likelihood Ratio) e t-Student. Resultados: As enfermeiras obstetras utilizaram majoritariamente as práticas da categoria A da OMS. Não houve diferença estatisticamente significativa nas associações entre as práticas e os desfechos perineais. Houve diferença estatisticamente significativa entre o peso do recém-nascido e o número de intercorrências neonatais e entre as posições de parto das primíparas com a fratura de clavícula dos recém-nascidos. Conclusão e implicações para a prática: As práticas baseadas em evidências são seguidas pelas enfermeiras obstetras no CPN analisado. Os desfechos maternos e neonatais mostraram-se adequados. Há necessidade de melhorar a assistência no segundo período do parto, evitando condutas que reflitam em intercorrências neonatais. O estudo possibilita a reflexão sobre a importância da avaliação continuada da assistência prestada.

Palavras-chave: Assistência ao parto; Saúde da mulher; Parto Normal; Trabalho de Parto; Enfermeiras Obstétricas.

\section{Resumen}

Objetivos: Caracterizar las prácticas utilizadas por las enfermeras obstetras en un Centro de Parto Normal (CPN) y verificar los resultados maternos y neonatales. Método: Estudio transversal, documental, retrospectivo, con abordaje cuantitativo, en el cual fueron analizados prontuarios de 300 parturientas que dieron a luz en hospital público de la ciudad de São Paulo. Los criterios adoptados para el análisis de las prácticas obstétricas fueron las categorías de la Organización Mundial de la Salud (OMS). Fueron utilizadas las pruebas, exacto de Fisher o razón de verosimilitud (Likelihood Ratio) y t-Student. Resultados: Las enfermeras obstetras utilizaron mayoritariamente las prácticas de la categoría A de la OMS. No hubo diferencia estadísticamente significativa en las asociaciones entre las prácticas y los resultados perineales. Se observó una diferencia estadísticamente significativa entre el peso del recién nacido y el número de intercurrencias neonatales, así como entre las posiciones de parto de las primíparas con la fractura de clavícula de los recién nacidos. Conclusión e implicaciones para la práctica: Las prácticas basadas en evidencias son seguidas por las enfermeras obstetras en el CPN analizado. Los resultados maternos y neonatales se mostraron adecuados. Es necesario mejorar la asistencia en el segundo período del parto para evitar conductas que reflejen en las interacciones neonatales. El estudio posibilita la reflexión sobre la importancia de la evaluación continuada de la asistencia prestada.

Palabras clave: Asistencia al parto; Salud de la mujer; Parto normal; Trabajo de Parto; Enfermeras Obstétricas. 


\section{INTRODUCTION}

Changing the scenario of obstetric care in Brazil is a challenge and requires structural alterations in the care services, changes in some cultural paradigms and, above all, the qualification of the professionals and the effective inclusion of midwives and nurse-midwives in order to contribute to the reduction of maternal and neonatal morbidity and mortality. ${ }^{1,2}$

One of the strategies used by the Brazilian Ministry of Health $(\mathrm{MH})$ to encourage the use of evidence-based practices in the birth and delivery process was the implantation, in 1999, of Natural Birth Centers (NBCs), ${ }^{3,4}$ places where preferably nurse-midwives and midwives provide the care.

From this perspective, studies ${ }^{5-8}$ comparing the care provided at the Obstetric Center (OC) and the NBC showed an improvement in childbirth care in the second model, since there were fewer perineal traumas and interventions such as analgesia, episiotomy and oxytocin use, as well as a lower number of transfers for operative deliveries.

Despite the efforts of the previous 20 years to implement public policies aimed at improving obstetric care, the results are still incipient, as demonstrated by the national survey published in $2014 .{ }^{9}$ This revealed the priority use of practices not recommended by the scientific evidence, leading the authors to corroborate with publications recommending the inclusion of midwives and nurse-midwives in order to collaborate with the transformation and improvement of the health care. ${ }^{10-12}$

As the strengthening and expansion of NBCs depend on the successful results of this care model, the present study aimed to characterize the practices used by nurse-midwives in an NBC and to verify the maternal and neonatal outcomes resulting from this care.

\section{METHOD}

This was a cross-sectional, documentary, retrospective study with a quantitative approach, carried out in a large, public, state institution in the city of São Paulo, which had existed for 25 years, with its hospital NBC inaugurated in 2005. In this place, which has eight suites, only nurse-midwives acted at the time of data collection, as there were no midwives on the staff of the institution.

The population was constituted by 1221 medical records of women that gave birth in the NBC in the year 2015. The STATS $2.0^{\circledR}$ statistical program was used for the sample calculation, considering the maximum acceptable percentage of error of $5 \%$, level of estimated percentage of $50 \%$ and confidence level of $95 \%$. The minimum sample size was 292 medical records and 300 were analyzed. Sampling was of the simple random type, that is, first a list was made with the number of all medical records that were then randomized by the Randomized.com ${ }^{\circledR}$ program.
The study included medical records that met the inclusion criteria: to belong to a woman with labor and delivery assisted exclusively by a nurse-midwife, and to be available in the file at the time of data collection. To avoid any bias, the medical records in which the care was provided by the first author of the study were excluded.

To collect the data, a form was designed based on the obstetric care recommendations of the World Health Organization $(\mathrm{WHO})^{13}$ and on Ordinance No. 11 of the $\mathrm{MH},{ }^{14}$ which present the indicators to be monitored in the NBC. This instrument contained three parts: the first collected sociodemographic and obstetric data of the women; the second information on the obstetric practices of the WHO; and the third maternal and neonatal outcomes.

The information was collected by the first author between the second half of 2016 and the first of 2017, after approval by the Research Ethics Committee of the Hospital, authorization number 1.429.319. The results are presented as parametric quantitative variables (mean and standard deviation) and nonparametric variables (median and interquartile range). The association between the categorical variables was assessed using Fisher's exact test or the Likelihood Ratio. Parametric variables were evaluated using Student's t-test or analysis of variance. Values of $p<0.05$ were considered statistically significant.

\section{RESULTS}

The profile of the 300 parturients can be defined as follows: they were young, had a median age of 22 years (minimum 13, maximum 43 years), lived with partners (69.0\%), had a median of 9 years of study, did not report the performance of paid activity (84.3\%), and were not users of alcohol (97.9\%) or illicit drugs $(94.9 \%)$. The obstetric data showed that the majority did not report previous preterm birth $(99.3 \%)$, miscarriage $(90.6 \%)$ or caesarean section (92.6\%), $63.6 \%$ had on average 7 prenatal consultations and $59.0 \%$ did not present complications during the pregnancy. The most frequent complications in the prenatal care were urinary tract infection (37.3\%), hypertension $(2.3 \%)$, diabetes (1.6\%) and sexually transmitted infections (6.0\%).

The mean cervical dilation of the women at the time of admission was six centimeters, and $68.3 \%$ had intact ovary membranes.

Regarding the category A practices, which are demonstrably useful, should be encouraged and are described in Table 1, the majority of women (94.6\%) had a companion throughout the parturition process and breastfed in the first hour after the birth (95.3\%). The non-pharmacological methods most used for pain relief were the shower $(51.7 \%)$ and walking (58.7\%). The majority $(98.3 \%)$ had a partograph completed and the delivery in a nonlithotomy position $(74.5 \%)$, with the semi-seated position being the most used $(62.2 \%)$. The placenta and membranes were inspected in $99.3 \%$ of the deliveries. 
Table 1. Recommended practices (category A) performed by nurse-midwives in a hospital NBC

\begin{tabular}{|c|c|}
\hline Practices in the childbirth care & n (\%) \\
\hline \multicolumn{2}{|l|}{ Companion of choice } \\
\hline Yes & $284(94.6)$ \\
\hline No & $11(3.7)$ \\
\hline Not mentioned in the medical record & $5(1.7)$ \\
\hline \multicolumn{2}{|l|}{$\begin{array}{l}\text { Breastfeeding in the first hour after the } \\
\text { delivery }\end{array}$} \\
\hline Yes & $286(95.3)$ \\
\hline No & $6(2.0)$ \\
\hline Not mentioned in the medical record & $8(2.7)$ \\
\hline \multicolumn{2}{|l|}{$\begin{array}{l}\text { Skin-to-skin contact for one continuous } \\
\text { hour after the delivery }\end{array}$} \\
\hline Yes & $183(61.0)$ \\
\hline No & $116(38.7)$ \\
\hline Not mentioned in the medical record & $1(0.3)$ \\
\hline \multicolumn{2}{|l|}{ Squatting during the labor } \\
\hline Yes & $34(11.3)$ \\
\hline Not mentioned in the medical record & $266(88.7)$ \\
\hline \multicolumn{2}{|l|}{ Shower during the labor } \\
\hline Yes & $155(51.7)$ \\
\hline Not mentioned in the medical record & $145(48.3)$ \\
\hline \multicolumn{2}{|l|}{ Use of the ball during the labor } \\
\hline Yes & $42(14.0)$ \\
\hline Not mentioned in the medical record & $258(86.0)$ \\
\hline \multicolumn{2}{|l|}{ Pelvic balance during the labor } \\
\hline Yes & $128(42.7)$ \\
\hline Not mentioned in the medical record & $172(57.3)$ \\
\hline \multicolumn{2}{|l|}{ Walking during the labor } \\
\hline Yes & $176(58.7)$ \\
\hline Not mentioned in the medical record & $124(41.3)$ \\
\hline \multicolumn{2}{|l|}{ Hydro massage during the labor } \\
\hline Yes & $25(8.3)$ \\
\hline Not mentioned in the medical record & $275(91.7)$ \\
\hline \multicolumn{2}{|l|}{ Massage during the labor } \\
\hline Yes & $32(10.7)$ \\
\hline Not mentioned in the medical record & $268(89.3)$ \\
\hline \multicolumn{2}{|l|}{$\begin{array}{l}\text { Freedom of position/movement during } \\
\text { the labor }\end{array}$} \\
\hline Yes & $249(83.0)$ \\
\hline Not mentioned in the medical record & $51(17.0)$ \\
\hline
\end{tabular}

continuation Table 1.

\begin{tabular}{lc}
\hline Practices in the childbirth care & $\mathbf{n}(\%)$ \\
\hline Partograph & \\
\hline Yes & $295(98.3)$ \\
No & $5(1.7)$ \\
\hline Position for the birth & $183(61.0)$ \\
\hline Semi-seated & $36(12.0)$ \\
Squatting, side or four supports & $75(25.0)$ \\
Lithotomy & $6(2.0)$ \\
\hline Not mentioned in the medical record & \\
\hline Oxytocin in the third period & $298(99.3)$ \\
\hline Yes & $2(0.7)$ \\
\hline Not mentioned in the medical record & \\
\hline Inspection of placenta and ovary & \\
membranes & $298(99.3)$ \\
\hline Yes & $2(0.7)$ \\
\hline
\end{tabular}

Regarding Category B practices, which are clearly harmful or ineffective, which should be eliminated and are described in Table 2, the lithotomy position obtained the highest percentage $(25.0 \%)$, with the other indices below $3.0 \%$. It was also observed that, in relation to practices that are frequently used improperly (category D), the most identified were rigid adherence of up to 10 minutes for the second period of labor $(79.0 \%)$, fetal electronic monitoring $(20.0 \%)$, pain control by systemic agents $(13.7 \%)$ and vaginal examinations by more than one nurse $(46.1 \%)$.

Regarding the perineal outcomes, the highest percentage of women (42.0\%) suffered first degree laceration, followed by intact perineum $(37.7 \%)$, episiotomy $(16.0 \%)$, second degree laceration $(4.0 \%)$ and third degree laceration $(0.3 \%)$. The primiparous women had a lower rate of intact perineum (9.7\%) and a higher rate of episiotomy (12.3\%), while the women with a previous natural birth presented intact perineum in higher percentages $(28.0 \%)$ and had a lower incidence of episiotomy (3.7\%).

Several associations of the practices with the perineal outcomes were investigated, and no statistically significant associations were found. It was found, for example, that the position of labor did not interfere with perineum conditions or vaginal bleeding in the immediate postpartum period.

Neonatal outcomes showed that the median weight of the newborns was $3212 \mathrm{~g}(S D=408.1$, minimum $2240 \mathrm{~g}$, maximum $4950 \mathrm{~g}) ; 73.0 \%$ of the babies had Apgar 9 or 10 in the first minute and $96.3 \%$ had 9 or 10 in the fifth minute. The majority did not undergo upper airway aspiration $(76.9 \%)$ or have complications during the delivery (95.0\%). Only 15 newborns presented complications, with $4.0 \%$ being clavicle fractures and $1.0 \%$ respiratory discomfort. 
Table 2. Practices not recommended (category B) or used inappropriately (category D) performed by nurse-midwives in the NBC

\begin{tabular}{|c|c|}
\hline Practices in the childbirth care & n (\%) \\
\hline \multicolumn{2}{|l|}{ CATEGORY B } \\
\hline \multicolumn{2}{|l|}{ Lithotomy position during the delivery } \\
\hline Yes & $75(25.0)$ \\
\hline No & $219(73.0)$ \\
\hline Not mentioned in the medical record & $6(2.0)$ \\
\hline \multicolumn{2}{|l|}{ Revision of uterine cavity after the delivery } \\
\hline Yes & $8(2.6)$ \\
\hline No & $290(96.7)$ \\
\hline Not mentioned in the medical record & $2(0.7)$ \\
\hline \multicolumn{2}{|l|}{$\begin{array}{l}\text { Use of parenteral ergometrine in the third } \\
\text { stage of labor }\end{array}$} \\
\hline Yes & $5(1.7)$ \\
\hline No & $295(98.3)$ \\
\hline \multicolumn{2}{|l|}{ CATEGORY D } \\
\hline \multicolumn{2}{|l|}{$\begin{array}{l}\text { Rigid adhesion to time of the second period } \\
\text { of labor }\end{array}$} \\
\hline Up to 10 minutes & $237(79.0)$ \\
\hline 11 and 30 minutes & $31(10.4)$ \\
\hline 31 and 60 minutes & $1(0.3)$ \\
\hline$>60$ minutes & $1(0.3)$ \\
\hline Not mentioned in the medical record & $30(10.0)$ \\
\hline \multicolumn{2}{|l|}{ Correction of uterine dynamics with oxytocin } \\
\hline Yes & $57(19.0)$ \\
\hline No & $243(81.0)$ \\
\hline \multicolumn{2}{|l|}{ Episiotomy } \\
\hline Yes & $48(16.0)$ \\
\hline No & $251(83.7)$ \\
\hline Not mentioned in the medical record & $1(0.3)$ \\
\hline \multicolumn{2}{|l|}{ Fetal electronic monitoring } \\
\hline None & $60(20.0)$ \\
\hline 1 to 2 & 231 (77.0) \\
\hline 3 to 4 & $9(3.0)$ \\
\hline \multicolumn{2}{|l|}{ Amniotomy } \\
\hline Yes & $17(5.6)$ \\
\hline No & $242(80.7)$ \\
\hline Not mentioned in the medical record & 41 (13.7) \\
\hline
\end{tabular}

continuation Table 2.

\begin{tabular}{|c|c|}
\hline Practices in the childbirth care & n (\%) \\
\hline \multicolumn{2}{|l|}{$\begin{array}{l}\text { Pain control by systemic agents (buscopan }{ }^{\circledR}, \\
\text { plasil }^{\circledR} \text { and glucose) }\end{array}$} \\
\hline Yes & $41(13.7)$ \\
\hline No & $259(86.3)$ \\
\hline \multicolumn{2}{|l|}{ Vaginal examination by more than one nurse } \\
\hline Yes & $137(45.7)$ \\
\hline No & $160(53.3)$ \\
\hline Not mentioned in the medical record & $3(1.0)$ \\
\hline
\end{tabular}

Table 3 shows that there was a statistical tendency between the lithotomy delivery position and neonatal complications $(p=0.08)$ and a statistically significant association between the weight of the newborn and the higher number of complications $(p=0.001)$.

The association between birth positions and clavicle fracture (Table 4) showed that there was a statistical tendency between the lithotomy position and the clavicle fracture in all deliveries $(p=0.08)$, with a statistically significant association in the primiparous women who gave birth in the lithotomy position $(p=0.001)$, that is, this position was associated with the clavicle fracture in the primiparous women.

Category C practices were not identified in the medical records, meaning that they were not performed.

\section{DISCUSSION}

The results demonstrate that the nurse-midwives mostly used the WHO category A recommendations, which has also been observed in other studies performed in NBCs. ${ }^{1,2}$ In this care model, these practices are more used when compared to those performed in OCs. ${ }^{5-8}$

The women had companions in $94.6 \%$ of the cases, a result similar to studies carried out in other childbirth centers. ${ }^{2,3}$ The benefits of the presence of a companion are numerous, especially the promotion of a calmer environment and the physical and emotional security for the women. ${ }^{15}$

The infants were breastfed and had skin-to-skin contact during the first hour of life $(95.3 \%$ and $61.0 \%)$. This difference is explained by the fact that the contact is only considered when the baby stays for one hour in the mother's arms, which is not always possible in the reality of the institution. These interventions are important for both the infant and the mother, since they strengthen the affective and family bond and facilitate continuity of the breastfeeding process. ${ }^{16,17}$

In relation to the non-pharmacological methods for pain relief, the shower, walking and pelvic balance were the most 
Table 3. Association between neonatal complication, delivery position and weight of newborn

\begin{tabular}{lccc}
\hline \multirow{2}{*}{ Variable } & \multicolumn{2}{c}{ Neonatal intercurrence* } & \multirow{2}{*}{-value } \\
\cline { 2 - 3 } & No $(\mathbf{n}=\mathbf{2 7 9})$ & Yes $(\mathbf{n}=\mathbf{1 5})$ & \\
\hline Delivery position & $69(92.0 \%)$ & $6(8.0 \%)$ & $0.080^{* *}$ \\
Lithotomy & $210(95.1 \%)$ & $9(4.9 \%)$ & $0.001^{* * *}$ \\
Not lithotomy & $3212+408$ & $3486+481$ & \\
Weight of the newborn & * Six records hat no information on the delivery position and & & \\
\hline
\end{tabular}

Table 4. Association of birth position with clavicle fracture of the newborn of all parturients and of the primiparous women

\begin{tabular}{|c|c|c|c|}
\hline \multirow{2}{*}{ Variable } & \multicolumn{2}{|c|}{ Clavicle fracture } & \multirow{2}{*}{$p$-value } \\
\hline & No $(n=287)$ & Yes $(n=12)$ & \\
\hline \multicolumn{4}{|c|}{ Delivery position $n=299$ )* } \\
\hline Lithotomy & $69(92.0 \%)$ & $6(8.0 \%)$ & $0.080^{* *}$ \\
\hline Not lithotomy & $218(97.3 \%)$ & $6(2.7 \%)$ & \\
\hline \multicolumn{4}{|c|}{ Delivery position of the primiparous women $(n=133)$} \\
\hline Lithotomy & $31(86.1 \%)$ & $5(13.9 \%)$ & $0.001^{* *}$ \\
\hline Not lithotomy & 97 (100\%) & $0(0.0 \%)$ & \\
\hline
\end{tabular}

used, however, to a lesser extent than in similar studies. ${ }^{2,3}$ It is important to emphasize that one of the benefits of alternative therapies for pain management is to give women the freedom to choose a measure of comfort that best fulfills their need. ${ }^{18}$ In addition, these practices and the freedom of position and movement during the labor, present in $83.0 \%$ of the records, are associated with relaxation, reduction in the number of interventions and reduction of the duration of the labor..$^{19-22}$

The partograph was used by $98.3 \%$ of the nurses, emphasizing its importance in the prevention of complications, interventions and surgical deliveries, as directed by the Guidelines for Natural Childbirth Care of the $\mathrm{MH}^{23}$, an important document that seeks to qualify childbirth care in Brazil through the use of evidencebased practices.

The majority of the women $(61.0 \%)$ gave birth in a semiseated position, which has also been identified in other studies. ${ }^{3,22}$ It should be noted that the lithotomy position has been less used or even abolished in other care settings ${ }^{2,3}$ because it results in a higher incidence of episiotomy and longer duration of the expulsive period. ${ }^{24,25}$

Oxytocin in the third period was used in $99.3 \%$ of the deliveries. Although indicated in category A only for women at risk of postpartum hemorrhage (PPH), or with a small amount of blood loss, a recent WHO recommendation ${ }^{26}$ suggested giving it to all women to prevent $\mathrm{PPH}$.

Regarding the categories $\mathrm{B}$ and $\mathrm{C}$ practices, it was verified that amniotomy was performed in $5.6 \%$ of the women, an index lower than what was found in other $\mathrm{NBCs}^{2,3,5}$ This procedure increases the risk of cesarean section, due to altered fetal heart rate, and should be used with caution and justification, ${ }^{27}$ as it can also lead to maternal and neonatal infection. ${ }^{23}$

The use of oxytocin during labor was present in $19.0 \%$, however, was not justified in $51.9 \%$ of the medical records. This practice, however, was less frequent than in other studies ${ }^{2,3,22}$ and was not associated with perineal lacerations or neonatal complications, a result similar to another investigation. ${ }^{28}$

Episiotomy was performed in $16.0 \%$ of the women, a percentage higher than other studies. ${ }^{29,30}$ This is a practice that is associated with iatrogenic consequences for the physical and psychosocial health of women and should therefore be avoided. ${ }^{23,29,30,31}$

The evidence indicates that there is no justification for the routine performance of episiotomy because its risks are greater than the benefits for women who have a spontaneous vaginal delivery. ${ }^{31}$ Furthermore, this is a practice frequently associated with obstetric violence, because it is usually performed without consent and results in pain, embarrassment and suffering. ${ }^{32}$

Electronic fetal monitoring (EFM) was performed one to two times in $70.0 \%$ of the women, and the current recommendations suggest intermittent fetal auscultation every 30 minutes, before, during and after the contraction, rather than EFM. ${ }^{23}$

During the expulsive period, the 10-minute constant was identified in $87.7 \%$ of the medical records, which suggests that the professionals are directing the maternal pushing to accelerate 
the expulsion, possibly believing that the shorter duration of the period results in better maternal and neonatal conditions. This practice, however, is incorrect; it is not recommended to stipulate a time nor direct pushing, since birth may occur up to two and a half hours after the active expulsive phase starts, in which total dilation of the cervix, visualization of the baby's head and contractions of expulsion or spontaneous maternal effort are observed. ${ }^{23}$

The clavicle fracture, which had a tendency to be significantly associated with the lithotomic position and which was statistically significant for the primiparas women and for the babies of greater weight, was identified in other studies, ${ }^{33-36}$ which showed a relationship between fracture and fetal macrosomia, and consequent shoulder dystocia, as well as with the use of vacuum extractor and oxytocin during labor.

The rates of fracture of this study are higher than those found in other studies ${ }^{34,35}$ which indicates the need to improve the care, to evaluate the real need for oxytocin during labor and to avoid the lithotomy position, directed pushing and active extraction of the shoulders in the expulsive period. According to the $\mathrm{WHO}^{37}$ and the $\mathrm{MH},{ }^{23}$ there is no evidence that fetal traction improves perinatal outcomes and, in addition, may increase the chances of perineal lacerations. The recommendation is that after the expulsion of the head the midwife should wait for the spontaneous birth of the shoulders and the rest of the fetal body, except in situations in which shoulder dystocia occurs, when the professional should follow the maneuvers recommended. ${ }^{23}$

Regardless of the use of practices not recommended or inadequately performed by the professionals of this study, it is important to highlight the role of nurse-midwives and midwives in the movement of humanization and of transformation of the delivery and birth care model and in the consequent prevention of obstetric violence. ${ }^{1}$

\section{CONCLUSIONS AND IMPLICATIONS FOR THE PRACTICE}

The annotations identified in the medical records allowed the conclusion that evidence-based practices (good practices) are being followed by nurse-midwives in the childbirth care of usual risk in the NBC analyzed. However, practices that are not recommended or that should be abolished are still used by them, even if in low percentages, which possibly reflects a care model that is not based on scientific evidence. The maternal and neonatal outcomes were mostly adequate. However, there is a need to improve the care in the second period of the delivery in order to avoid conduct that reflects in neonatal complications.

Among the limitations of the study, the use of secondary data from medical records, in which the registrations do not necessarily mean that the actions occurred, is a primary consideration. In addition, the lack of some registrations should also be considered as a bias that interferes with the results. However, despite this, it should be mentioned that medical records are used as an important source of data for scientific investigations, even if they do not always present all the information necessary for the assessment of the care. Another limitation is related to the fact that data collected was from the medical records of women accompanied by nurse-midwives throughout the birth and delivery process. The practices used by these professionals with the women transferred from the NBC to the $\mathrm{OC}$ due to some intercurrence during labor are unknown.

It is believed that the results presented here can contribute to stimulate not only the implementation of a greater number of NBCs but also to highlight the quality of the work of nurse-midwives and/or midwives, professionals recently included in the nursing teams and, as a priority, prepared for the promotion of a humanized and non-interventionist care model in the delivery and birth process. Another relevant contribution is the possibility of reflecting on the importance of systematically evaluating the results of practices in order to detect and correct fragilities that interfere with qualified care for women.

\section{REFERENCES}

1. Narchi NZ, Cruz EF, Gonçalves R. The role of midwives and nursemidwives in promoting safe motherhood in Brazil. Ciên Saúde Colet [Internet]. $2013 \mathrm{abr}$; [cited 2019 mai 18]; 18(4):1059-68. Available from: http://dx.doi.org/10.1590/S1413-81232013000400019

2. Pereira ALF, Lima TRL, Schroeter MS, Gouveia MSF, Nascimento SD. Resultados maternos e neonatais da assistência em casa de parto no município do Rio de Janeiro. Esc Anna Nery [Internet]. 2013 mar; [cited 2018 oct 30]; 17(1):17-23. Available from: http://dx.doi.org/10.1590/ S1414-81452013000100003

3. Silva FMB, Paixão TCR, Oliveira SMJV, Leite JS, Riesco MLG, Osava $\mathrm{RH}$. Assistência em um centro de parto segundo as recomendações da Organização Mundial da Saúde. Rev Esc Enferm USP [Internet]. 2013 oct; [cited 2018 oct 30]; 47(5):1031-8. Available from: http://dx.doi. org/10.1590/S0080-623420130000500004

4. Portaria n. 985 de 05 de agosto de 1999 (BR). Cria o Centro de Parto Normal-CPN, no âmbito do Sistema Único de Saúde/SUS, para o atendimento à mulher no período gravídico-puerperal. Diário Oficial da União [Internet], Brasília (DF). 05 ago 1999 [cited 2018 dec 13]. Available from: http://www.saude.sp.gov.br/resources/humanizacao/ biblioteca/leis/parto-e-nascimento/portaria_985_1999_cpn.pdf

5. Schneck CA, Riesco MLG, Bonadio IC, Diniz CSG, Oliveira SMJV. Resultados maternos e neonatais em um centro de parto peri-hospitalar e hospitais. Rev Saúde Pública [Internet]. 2012 fev; [cited 2018 oct 30]; 46(1):77-86. Available from: http://dx.doi.org/10.1590/S003489102012000100010

6. Rocha FR, Melo MC, Medeiros GA, Pereira EP, Boeckmann LMM, Dutra LMA. Análise da assistência ao binômio mãe-bebê em centro de parto normal. Cogitare Enferm [Internet]. 2017; [cited 2018 oct 30]; 22(2):e49228. Available from: http://dx.doi.org/10.5380/ce.v22i2.49228

7. Kuliukas L, Duggan R, Lewis L, Hauck Y. Women's experience of intrapartum transfer from a Western Australian birth centre co-located to a tertiary maternity hospital. BMC Pregnancy Childbirth [Internet]. 2016 feb; [cited 2018 dec 13]; 16:33. Available from: https://doi.org/10.1186/ s12884-016-0817-z

8. Overgaard C, Møller AM, Fenger-Grøn M, Knudsen LB, Sandall J. Freestanding midwifery unit versus obstetric unit: a matched cohor study of outcomes in low-risk women. BMJ Open [Internet].2011; [cited 2018 dec 13]; 1:e000262. Available from: http://dx.doi.org/10.1136/ bmjopen-2011-000262 
9. Leal MC, Pereira APE, Domingues RMSM, Theme Filha MM, Dias MAB, Nakamura-Pereira M, et al. Intervenções obstétricas durante o trabalho de parto e parto em mulheres brasileiras de risco habitual. Cad Saúde Pública [Internet]. 2014; [cited 2018 oct 30]; 30(Suppl 1):S17-S32. Available from: http://dx.doi.org/10.1590/0102-311X00151513

10. United Nations Population Fund (USA). UNFPA Maternal Mortality Update 2006. Expectation and Delivery: Investing in Midwives and Others with Midwifery Skills [Internet]. New York: UNFPD; 2007; [cited $2018 \mathrm{dec} 13]$. Available from: https://www.unfpa.org/sites/default/files/ pub-pdf/mm_update06_eng.pdf

11. United Nations Population Fund (USA). Towards MDG 5: Scaling up the capacity of midwives to reduce maternal mortality and morbidity. Workshop Report [Internet]. New York: UNFPA; 2006 mar; [cited 2018 dec 13]. Available from: https://www.unfpa.org/sites/default/files/ resource-pdf/midwives_mm.pdf

12. Hodnett ED, Gates S, Hofmeyr GJ, Sakala C, Weston J. Continuous support for women during childbirth. Cochrane Database Syst Rev [Internet]. 2011 feb; [cited 2019 mai 18]; (2):CD003766. Available from: https://www.cochranelibrary.com/cdsr/doi/10.1002/14651858. CD003766.pub6

13. World Health Organization (WHO). Care in normal birth: a practical guide. Geneva: WHO; 1996.

14. Portaria n. 11 de 07 de janeiro de 2015 (BR). Redefine as diretrizes para implantação e habilitação de Centro de Parto Normal (CPN), no âmbito do Sistema Único de Saúde (SUS), para o atendimento à mulher e ao recém-nascido no momento do parto e do nascimento, em conformidade com o Componente PARTO E NASCIMENTO da Rede Cegonha, e dispõe sobre os respectivos incentivos financeiros de investimento, custeio e custeio mensal. Diário Oficial da União [Internet], Brasília (DF). 07 jan 2015 [cited 13 dec 2018]. Available from: http://bvsms.saude.gov. br/bvs/saudelegis/gm/2015/prt0011_07_01_2015.html

15. Dodou HD, Rodrigues DP, Guerreiro EM, Guedes MVC, Lago PN, Mesquita NS. A contribuição do acompanhante para a humanização do parto e nascimento: percepções de puérperas. Esc Anna Nery [Internet]. 2014; [cited 2019 mar 7]; 18(2):262-9. Available from: http:// dx.doi.org/10.5935/1414-8145.20140038

16. Fucks IS, Soares MC, Kerber NPC, Meincke SMK, Escobal APL, Bordignon SS. A sala de parto: o contato pele a pele e as ações para o estímulo ao vínculo entre mãe-bebê. Rev Enferm [Internet]. 2015 jan; [cited 2019 mar 7]; 33(1):29-37. Available from: http://dx.doi. org/10.15446/av.enferm.v33n1.47371

17. Guinsburg R, Almeida MFB. Reanimação do recém-nascido $<34$ semanas em sala de parto: Diretrizes 2016 da Sociedade Brasileira de Pediatria [Internet]. 2016 jan; [cited 2018 jul 13]. Available from: http:// www.sbp.com.br/fileadmin/user_upload/DiretrizesSBPReanimacaoPrematuroMenor34semanas26jan2016.pdf

18. Mafetoni RR, Shimo AKK. Métodos não farmacológicos para alívio da dor no trabalho de parto: revisão integrativa. REME [Internet]. $2014 \mathrm{abr} /$ jun; [cited 2018 jul 13]; 18(2):505-12. Available from: http://www.dx.doi. org/10.5935/1415-2762.20140037

19. Mosquera Pan P, Onandia Garate M, Luces Lago AM, Tizón Bouza E. Inmersion in hot water: a natural helper in labor. Rev Enferm. 2016 jan;39(1):25-30.

20. Henrique AJ, Gabrielloni MC, Cavalcanti ACV, Melo PS, Barbieri M. Hidroterapia e bola suíça no trabalho de parto: ensaio clínico randomizado. Acta Paul Enferm [Internet]. 2016 dez; [cited 2018 jul 13]; 29(6):686-92. Available from: http://dx.doi.org/10.1590/19820194201600096

21. Smith CA, Levett KM, Collins CT, Jones L. Massage, reflexology and other manual methods for pain management in labour. Cochrane Database Syst Rev [Internet]. 2012 feb; [cited 2018 jul 13]; (2):CD009290. Available from: https://www.cochranelibrary.com/cdsr/doi/10.1002/14651858. CD009290.pub3

22. Côrtes CT, Santos RCS, Caroci AS, Oliveira SG, Oliveira SMJV, Riesco MLG. Metodologia de implementação de práticas baseadas em evidências científicas na assistência ao parto normal: estudo piloto. Rev Esc Enferm USP [Internet]. 2015 oct; [cited 2018 jul 13]; 49(5):716-25. Available from: http://dx.doi.org/10.1590/S0080-623420150000500002
23. Ministério da Saúde (BR). Secretaria de Ciência, Tecnologia e Insumos Estratégicos. Diretriz Nacional de Assistência ao Parto Normal. Relatório de recomendação. Brasília (DF): Ministério da Saúde [Internet]; 2016 jan; [cited 2018 dec 13]. Available from: http://conitec.gov.br/images/ Consultas/2016/Relatorio_Diretriz-PartoNormal_CP.pdf

24. Elvander C, Ahlberg M, Thies-Lagergren L, Cnattingius S, Stephansson $O$. Birth position and obstetric anal sphincter injury: a population-based study of 113000 spontaneous births. BMC Pregnancy Childbirth [Internet]. 2015 oct; [cited 2018 jul 13]; 15:252. Available from: https:// doi.org/10.1186/s12884-015-0689-7

25. Gupta JK, Hofmeyr GJ, Shermar M. Position in the second stage of labour for women without epidural anaesthesia. Cochrane Database Syst Rev [Internet]. 2012 may; [cited 2018 jul 13]; 16(5):CD002006. Available from: https://doi.org/10.1002/14651858.CD002006.pub3

26. Organização Mundial da Saúde (OMS). Recomendações da OMS para a prevenção e tratamento da hemorragia pós-parto. Genebra: OMS;2014 [cited $2018 \mathrm{dec}$ 13]. Available from: https://apps.who.int/iris/bitstream/ handle/10665/75411/9789248548505_por.pdf?sequence $=12$

27. Nogueiro EPSP. Aquisição de competências: contributos de uma revisão integrativa sobre a amniotomia precoce para a gestão do primeiro período de trabalho de parto [dissertação]. Porto (Portugal): Escola Superior de Enfermagem do Porto; 2014.

28. Hidalgo-Lopezosa P, Hidalgo-Maestre M, Rodríguez-Borrego MA. Labor stimulation with oxytocin: effects on obstetrical and neonatal outcomes. Rev Latino-Am Enferm [Internet]. 2016; [cited 2018 jul 13]; 24:e2744. Available from: http://dx.doi.org/10.1590/1518-8345.0765.2744

29. Frigo J, Cagol G, Zocche DA, Zanotelli SS, Rodrigues RM, Ascari RA Episiotomy: (un) knowledge about the procedure under the perspective of woman. Brazilian Journal of Surgery and Clinical Research [Internet]. $2014 \mathrm{mar} / \mathrm{mai}$; [cited $2018 \mathrm{dec}$ 13]; 6(2):5-10. Available from: https:// www.mastereditora.com.br/periodico/20140403_200543.pdf

30. Riesco MLG, Costa ASC, Almeida SFS, Basile ALO, Oliveira SMJV. Episiotomia, laceração e integridade perineal em partos normais: análise de fatores associados. Rev Enferm UERJ [Internet]. 2011 jan/ mar; [cited $2018 \mathrm{dec} 13$ ]; 19(1):77-83. Available from: http://www.facenf. uerj.br/v19n1/v19n1a13.pdf

31. Jiang H, Qian X, Carroli G, Garner P. Selective versus routine use of episiotomy for vaginal birth. Cochrane Database of Systematic Reviews [Internet]. $2017 \mathrm{feb}$; [cited $2018 \mathrm{dec}$ 7]; 8(2):CD000081. Available from: http://dx.doi.org/10.1002/14651858.CD000081.pub3

32. Zanardo GLP, Uribe MC, Nadal AHR, Habigzang LF. Violência obstétrica no Brasil: uma revisão narrativa. Psicol Soc [Internet]. 2017; [cited 2018 dec 7]; 29:e155043. Available from: https://dx.doi.org/10.1590/18070310/2017v29155043

33. Karahanoglu E, Kasapoglu T, Ozdemirci S, Fadıloglu E, Akyol A, Demirdag $E$, et al. Risk factors for clavicle fracture concurrent with brachial plexus injury. Arch Gynecol Obstet [Internet]. 2016 apr; [cited 2018 dec 7]; 293(4):783-7. Available from: https://doi.org/10.1007/ s00404-015-3917-5

34. Ahn ES, Jung MS, Lee YK, Ko SY, Shin SM, Hahn MH. Neonata clavicular fracture: recent 10 year study. Pediatr Int [Internet]. $2014 \mathrm{sep}$ [cited 2018 dec 7]; 57(1):60-3. Available from: https://doi.org/10.1111/ ped. 12497

35. Lurie S, Wand S, Golan A, Sadan O. Risk factors fractures clavicle in the newborn. J Obstet Gynaecol Res. [Internet]. 2011 jul; [cited 2018 dec 7]; 37(11):1572-4. Available from: https://doi.org/10.1111/j.14470756.2011.01576.x

36. Iskender C, Kaymak O, Erkenekli K, Ustunyurt E, Uygur D, Yakut HI, et al. Neonatal injury at cephalic vaginal delivery: a retrospective analysis of extent of association with shoulder dystocia. PLoS One [Internet] 2014 aug; [cited $2018 \mathrm{dec}$ 7]; 9(8):e104765. Available from: https://doi. org/10.1371/journal.pone.0104765

37. World Health Organization (WHO).WHO recommendations: intrapartum care for a positive childbirth experience. Geneva: World Health Organization; 2018; [cited 2018 dec 13]. Available from: https://apps. who.int/iris/bitstream/handle/10665/260178/9789241550215-eng. pdf? sequence $=1$ 